\title{
Monomeric and dimeric copper (II) complexes based on bidentate N'- (propan-2-ylidene) thiophene carbohydrazide Schiff base ligand: Synthesis, structure, magnetic properties, antioxidant and anti- Alzheimer activities
}

\author{
Imed-Eddine Boulguemh, ${ }^{[\mathrm{a}]}$ Adel Beghidja, ${ }^{[\mathrm{a}]}$ Latifa Khattabi, ${ }^{[\mathrm{b}]}$ Jérôme Long, ${ }^{[\mathrm{c}]}$ and \\ Chahrazed Beghidja ${ }^{[a]^{*}}$
}

[a] Unité de Recherche de Chimie de l'Environnement et Moléculaire Structurale (CHEMS), Université frères Mentouri Constantine, Route Aïn elbey, 25000 Constantine, (Algérie). E-mail : cbeghidja@umc.edu.dz

[b] Centre de Recherche en Biotechnologie, Ali Mendjeli Nouvelle Ville UV 03, 25000 Constantine, Algérie.

[c] Institut Charles Gerhardt Montpellier, UMR 5253, Ingénierie Moléculaire et Nano-Objets, Université de Montpellier, ENSCM, CNRS, Place E. Bataillon, 34095 Montpellier Cedex 5 (France).

\begin{abstract}
The present study deals with the synthesis and characterization by single-crystal X-ray analysis and IR spectroscopy of two new Copper (II) complexes with bidentate Schiff base ligand [N'-(propan-2-ylidene) thiophene-2-carbohydrazide] (HL). Depending on the copper salt used in the synthesis, a mononuclear or doubly chloro bridged dinuclear Copper (II) complexes of respective formula $\left[\mathrm{Cu}(\mathrm{L})_{2}\right]$ (1) and $\left[\mathrm{Cu}_{2}(\mu-\mathrm{Cl})_{2}(\mathrm{HL})_{2} \mathrm{Cl}_{2}\right]$ (2) have been obtained. Magnetic study of complex 2 indicates the presence of weak antiferromagnetic interactions between the metal centers. To determine the antioxidant properties of both complexes, the ABTS radical scavenging and the reduction of copper (II)-neocuproine [Cu(II)-Nc] (CUPRAC) methods were used; 1 was more efficient than 2, for the two antioxidants assays. Lastly, Anti AChE activity method has been used to estimate in vitro anti-Alzheimer effect of $\mathbf{1}$ and $\mathbf{2}$ both of which show a potent AChE inhibition.
\end{abstract}

\section{Keywords:}

$\mathrm{Cu}(\mathrm{II})$ complexes / X-ray crystal structure / Chloro-bridge / Magnetic properties / Antioxidant / Anti-Alzheimer activities. 


\section{Introduction}

Schiff bases are an interesting class of ligands which have played a key role in the development of coordination chemistry due to their synthetic flexibility, selectivity and sensitivity towards the central metal ion and their ability to form stable complexes. ${ }^{[1-4]}$ Metal complexes of Schiff bases have been widely investigated because of their applications in various fields. Such complexes have an important role in the bio-inorganic chemistry, ${ }^{[5-8]}$ molecular magnetism ${ }^{[9,10]}$ or act as catalysts in different reactions such as selective insertion of oxygen into different organic molecules. ${ }^{[11-15]}$ Numerous studies have reported that this class of compounds containing various donor atoms (such as $\mathrm{N}, \mathrm{O}$ and $\mathrm{S}$ ) have exhibited excellent antioxidant, antitumor, anti-inflammatory, antimicrobial activities and are of special interest because of the variety of ways in which they are bonded to the transition metal ions. ${ }^{\left[{ }^{16-20]}\right.}$ Especially, sulfur is an essential component in normal physiological function and incorporated into amino acids, including cysteine, methionine, taurine, glutathione (GSH), Nacetylcysteine (NAC), and other sulfur compounds. It is an essential part of many antioxidant molecules (glutathione, thioredoxin and glutaredoxin), some sulfur-containing compounds can efficiently form a line of defense against reactive oxygen and nitrogen species. Metal binding by sulfur antioxidants may also afford significant protection against cellular oxidative damage and prevent oxidative damage which is also very important for the reduction of metal toxicity, they are well known in the treatment of oxidative stress induced pathological disorders. ${ }^{[21,22]}$ Furthermore, some dichloro bridged dinuclear $\mathrm{Cu}$ (II) complexes, based on a Schiff base ligand, have been investigates for their ability to act as anticancer agents. ${ }^{[23-25]}$ In addition to their various biological activities, polynuclear complexes of Schiff bases containing paramagnetic centers connected through various types of bridges $(\mathrm{OH}, \mathrm{OR}, \mathrm{Cl})$ have attracted considerable interest because they possess the essential structural features for the study of magnetic interactions between the magnetic centers. ${ }^{[26-31]}$ Dimeric $\mathrm{Cu}$ (II) complexes with $\mathrm{Cu}(\mu-\mathrm{Cl})_{2} \mathrm{Cu}$ core, have aroused chemists' interests due to the potential applications in the field of magnetic materials, ${ }^{[30,32-36]}$ this class of dinuclear compounds show a variety of structures ranging from square pyramid to trigonal bipyramid with diverse bond distances $(\mathrm{Cu}-\mathrm{Cl})$ and angles $(\mathrm{Cu}-\mathrm{Cl}-\mathrm{Cu})$ depending on the nature of the coordinated ligands. ${ }^{[37]}$

Here, we report the synthesis, crystal structures, magnetic properties, antioxidant and anti-alzheimer activities of two complexes with $\mathrm{Cu}$ (II) ions based on N'-(propan-2-ylidene) thiophene-2-carbohydrazide ligand. 


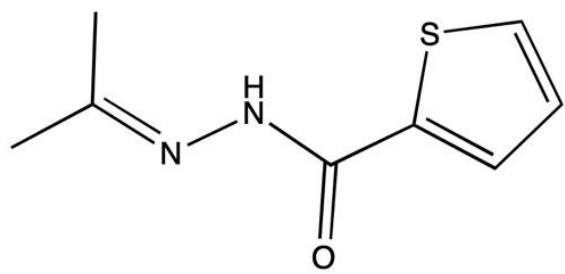

Scheme 1. Schematic representation of N'-(propan-2-ylidene) thiophene-2-carbohydrazide ligand (HL)

\section{Experimental}

\subsection{Materials}

Thiophene-2-carboxylic hydrazide, $\mathrm{Cu}(\mathrm{OAc})_{2} \cdot \mathrm{H}_{2} \mathrm{O}$ and $\mathrm{CuCl}_{2} \cdot 2 \mathrm{H}_{2} \mathrm{O}$, were purchased from Alfa Aesar. All the reagents and solvents were used as received without further purification. EnSpire Multimode plate reader PerkinElmer was used for measuring the absorbance, procedures were carried out on 96-well microplate. Chemical products include: Methanol for analysis and Ethanol absolute purchased from EMSURE, ABTS 2,2'-Azino-bis(3ethylbenzothiazoline-6-sulfonic acid) diammonium salt, Neocupronine, DTNB (6,6'-Dinitro3,3'-dithiodibenzoic acid), Acetylcholinesterase from Electrophorus electricus (electric eel) AChE 500 UNITS, Butylated hydroxytoluene $\geq 99 \%$, FCC, FG $\left(\mathrm{CH}_{3}\right)_{3} \mathrm{C}_{2} \mathrm{C}_{6} \mathrm{H}_{2}\left(\mathrm{CH}_{3}\right) \mathrm{OH}$, Butylated hydroxyanisole $\geq 98.5 \%\left(\mathrm{CH}_{3}\right)_{3} \mathrm{CC}_{6} \mathrm{H}_{3}\left(\mathrm{OCH}_{3}\right) \mathrm{OH}$, Sodium phosphate monobasic and $\mathrm{NaH}_{2} \mathrm{PO}_{4}$ Sodium phosphate dibasic $\mathrm{Na}_{2} \mathrm{HPO}_{4}$ were all purchased from Sigma-Aldrich, Persulfate de Potassium $\mathrm{K}_{2} \mathrm{~S}_{2} \mathrm{O}_{8}$ from Fluka, Copper chlorid II from VWR CHEMICALS, Ammonium acetate, extra pure $\mathrm{CH}_{3} \mathrm{COONH}_{4}$ from Scharlau, Acetylthiocholine iodide from AppliChem, Galantamine Hydrobromide USP.

\subsection{Physical Measurements}

Elemental analysis (C, H, N, S) was carried out with a Perkin-Elmer 2400 elemental analyzer.

FT-IR spectra, in the region $400-4000 \mathrm{~cm}^{-1}$, were recorded on a Perkin-Elmer Spectrum Two on ATR mode. Magnetic susceptibility data were collected with a Quantum Design MPMSXL SQUID magnetometer working in the $1.8-350 \mathrm{~K}$ temperature range with the applied magnetic field up to 7 Tesla. The data were corrected for the sample holder and the diamagnetic contributions calculated from Pascal's constants. Susceptibility was measured on heating in an applied field of 0.1 Tesla.

\subsection{Antioxidant and neuroprotective in-vitro activities}

Compound 1 and $\mathbf{2}$ were investigated for their antioxidant potential, by means of two distinct in vitro methods, and for their neuroprotective effect by means of an in vitro antialzheimer 
assay (anti acetylcholinesterase (AChE) activity). The results were compared with those of standards (positive controls) including: Butylated Hydroxyl Anisole (BHA); Butylated HydroxylToluene (BHT) (for antioxidant assay) and Galantamine (for anti-alzheimer assay).

\subsubsection{ABTS radical (ABTS•+) scavenging assay}

The assay was performed according to the method of Re et $a l .{ }^{[38]}$ with slight modifications. It consists to add $160 \mu \mathrm{L}$ of ABTS $\bullet+$ solution (7 mM ABTS dissolved in water and $2.45 \mathrm{mM}$ potassium persulfate $\left(\mathrm{K}_{2} \mathrm{~S}_{2} \mathrm{O}_{8}\right)$, stored in dark at room temperature for 16 hours. By diluting, the solution absorbance was adjusted to $0.700 \pm 0.020$ at $734 \mathrm{~nm}$ ) to $40 \mu \mathrm{L}$ of sample solution at different concentrations in methanol, then it was incubated for 10 minutes in a darkroom, the mixture absorbance was measured at $734 \mathrm{~nm}$.

The scavenging potential of ABTS•+ was evaluated by calculating the inhibition percentage

$(\mathrm{I} \%)$, following this formula : I \% $=\frac{(\mathrm{Ab}-\mathrm{As})}{\mathrm{Ab}} \times 100$

$\mathrm{Ab}$ absorbance of the blank (methanol instead of sample).

As absorbance of sample.

The sample concentration $(\mu \mathrm{M})$ inhibiting $50 \%$ of ABTS $\bullet$ (IC50) was estimated from the curve of ABTS $\bullet+\mathrm{I} \%$ correlated to the sample concentrations.

\subsubsection{Cupric ion reducing antioxidant capacity (CUPRAC)}

The CUPRAC (CUPric Reducing Antioxidant Capacity) was assessed by the method described previously with minor changes. ${ }^{[39]}$ A $40 \mu \mathrm{L}$ of sample solution at different concentrations was added by $50 \mu \mathrm{L} \mathrm{CuCl}_{2}(10 \mathrm{mM}), 50 \mu \mathrm{L}$ neocuproine in ethanol $(7.5 \mathrm{mM})$, and $60 \mu \mathrm{L} \mathrm{NH}_{4} \mathrm{AC}$ buffer (1 M, pH 7.0). The mixture was then left for $60 \mathrm{~min}$ before reading the absorbance at $450 \mathrm{~nm}$. The concentration $(\mu \mathrm{M})$ giving an absorbance of 0.5 (A0.5) was determined from the absorbance curves.

\subsubsection{Anti acetylcholinesterase activity}

Anti AChE activity is the standard method used to estimate the in vitro anti-Alzheimer effect, the procedure that was used followed method of Ellman, ${ }^{[40]}$ with a few modifications. several concentrations of product solutions $(10 \mu \mathrm{L})$ were added to $150 \mu \mathrm{L}$ of sodium phosphate buffer (100 mM, pH 8.0), then $20 \mu \mathrm{L} \mathrm{AChE} \mathrm{(5.32 \times 10-3} \mathrm{U)} \mathrm{solution} \mathrm{was} \mathrm{mixed} \mathrm{and} \mathrm{incubated} \mathrm{for} 15$ minutes at $25{ }^{\circ} \mathrm{C}$, after that a $10 \mu \mathrm{L}$ of $0.5 \mathrm{mM}$ DTNB was added. The reaction was then initiated by the addition of $10 \mu \mathrm{L}$ of acetylthiocholine iodide $(0.71 \mathrm{mM})$. The formation of the yellow 5-thio-2-nitrobenzoate anion as a result of the reaction was monitored spectrophotometrically at $412 \mathrm{~nm}$. \% of AChE inhibition was calculated using this equation: 
$\mathrm{I} \%=\frac{(\mathrm{E}-\mathrm{S})}{\mathrm{E}} \times 100$, where $\mathrm{E}$ is the activity of the enzyme without test sample, and $\mathrm{S}$ is the activity of the enzyme with test sample. IC50 $(\mu \mathrm{M})$ values were determined by plotting the inhibition percentage versus extract solution concentrations.

\subsubsection{Statistical analysis}

All experiments were performed in triplicate $(\mathrm{n}=3)$ and data are presented as mean \pm standard deviation (SD). The concentration giving 50\% inhibition (IC50) was calculated with Excel Microsoft Office Professional Plus 2013.

\subsection{Synthesis of the complexes $\left[C u^{I I} L_{2}\right](1)$ and $\left[C u^{I I}(\mu-C l)(C l)(L)\right]_{2}(2)$}

Thiophene-2-carboxylic hydrazide $(0.0284 \mathrm{~g}, 0.2 \mathrm{mmol})$ and sodium hydroxide $(0.008 \mathrm{~g}, 0.2$ mmol) were dissolved in a mixture of ethanol-acetone (3:1) $30 \mathrm{~mL}$. After 30 minutes of stirring $\mathrm{Cu}(\mathrm{OAc})_{2} \cdot \mathrm{H}_{2} \mathrm{O}(0.018 \mathrm{~g}, 0.1 \mathrm{mmol})$ and $\mathrm{CuCl}_{2} \cdot 2 \mathrm{H}_{2} \mathrm{O}(0.017 \mathrm{~g}, 0.1 \mathrm{mmol})$ were added respectively for the complex $\mathbf{1}$ and $\mathbf{2}$, the solutions were kept under stirring for 30 extra minutes. The resulting solutions affords upon slow evaporation the formation of green crystals suitable for X-ray analyses in $(0.022 \mathrm{~g}, 52 \%)$ and $(0.012 \mathrm{~g}, 38 \%)$ yield respectively for complexes 1 and 2 on the basis of $\mathrm{Cu}(\mathrm{OAc})_{2} \cdot \mathrm{H}_{2} \mathrm{O}$ for $\mathbf{1}$ and $\mathrm{CuCl}_{2} \cdot 2 \mathrm{H}_{2} \mathrm{O}$ for 2 . The antisymmetric $\boldsymbol{v}_{\text {as }}(\mathbf{C}-\mathbf{S})$ and symmetric stretching frequency $\mathbf{v}_{\mathbf{s}}(\mathbf{C}-\mathbf{S})$ for both complexes are observed at: 550, 570, 700 and 710 and for $(\mathrm{C}=\mathrm{N})$ around $1670 \mathrm{~cm}^{-1}$. Elemental Anal. Calcd. $\mathrm{C}_{16} \mathrm{H}_{18} \mathrm{CuN}_{4} \mathrm{O}_{2} \mathrm{~S}_{2}, \mathrm{C}: 45.10 ; \mathrm{H}: 4.26 ; \mathrm{N}: 13.15 ; \mathrm{S}: 15.05 \%$. Found: C: 44.92; H: 4.10; N: 13.45; S: $42.5 \%$ for 1. Calcd. $\mathrm{C}_{16} \mathrm{H}_{20} \mathrm{Cl}_{4} \mathrm{Cu}_{2} \mathrm{~N}_{4} \mathrm{O}_{2} \mathrm{~S}_{2}, \mathrm{C}: 30.34 ; \mathrm{H}: 3.18$; N: 8.84; S: $10.12 \%$. Found: C: 30.02; H: 3.38; N: 9.03; S: 10.31\% For 2.

\subsection{X-ray crystallography}

Diffraction intensities for complexes 1 and $\mathbf{2}$ were collected on a Bruker-AXS APEX II CCD diffractometer at 296(2) K. The crystallographic data, details of the intensity data collections and structure refinements are listed in Table 1. The intensities were collected with Mo K $\alpha$ radiation $(\lambda=0.71073 \AA)$. Data processing, Lorentz-polarization were performed using APEX. ${ }^{[41]}$ The structures were solved by direct methods and refined by full-matrix least-squares methods on $\mathrm{F}^{2}$, using the SHELXL-2018 program package. ${ }^{[42]}$ All non-hydrogen atoms were refined anisotropically. Hydrogen atoms in 1-2 were placed in calculated positions and were refined in the "riding" model with $U(H)_{i s o}=1.2 U_{e q}$ of their parent atoms $\left(U(H)_{i s o}=1.5 U_{e q}\right.$ for methyl groups $)$. Molecular plots were performed with the CrystalMaker and Mercury programs. ${ }^{[43,44]}$ Geometrical calculations were carried out with PLATON. ${ }^{[45]}$ CCDC- 1959149 (1) and 1959150 (2) 
contains the supplementary crystallographic data for this paper. These data are provided free of charge by The Cambridge Crystallographic Data Centre: ccdc.cam.ac.uk/structures.

Table 1: Crystal data and structure refinement for $\mathbf{1}$ and $\mathbf{2 .}$

\begin{tabular}{|c|c|c|}
\hline Identification code & 1 & 2 \\
\hline Empirical formula & $\mathrm{C}_{16} \mathrm{H}_{18} \mathrm{CuN}_{4} \mathrm{O}_{2} \mathrm{~S}_{2}$ & $\mathrm{C}_{16} \mathrm{H}_{20} \mathrm{Cl}_{4} \mathrm{Cu}_{2} \mathrm{~N}_{4} \mathrm{O}_{2} \mathrm{~S}_{2}$ \\
\hline Formula weight & 426.00 & 633.36 \\
\hline Temperature/K & 296 & 296 \\
\hline Crystal system & monoclinic & monoclinic \\
\hline Space group & $\mathrm{P} 2_{1} / \mathrm{n}$ & $\mathrm{C} 2 / \mathrm{c}$ \\
\hline $\mathrm{a} / \AA$ & 7.1221(10) & $10.9490(3)$ \\
\hline $\mathrm{b} / \AA$ & $11.9489(16)$ & $17.8037(5)$ \\
\hline$c / \AA$ & $10.8718(15)$ & $13.1661(4)$ \\
\hline$\alpha /^{\circ}$ & 90 & 90 \\
\hline$\beta /{ }^{\circ}$ & $101.612(3)$ & $109.1420(10)$ \\
\hline$\gamma /{ }^{\circ}$ & 90 & 90 \\
\hline Volume $/ \AA^{3} ; \mathrm{Z}$ & $906.3(2) ; 2$ & $2424.60(12) ; 4$ \\
\hline$\rho_{\text {calc }} \mathrm{g} / \mathrm{cm}^{3}$ & 1.561 & 1.735 \\
\hline$\mu / \mathrm{mm}^{-1}$ & 1.453 & 2.388 \\
\hline $\mathrm{F}(000)$ & 438.0 & 1272.0 \\
\hline Crystal size $/ \mathrm{mm}^{3}$ & $0.14 \times 0.13 \times 0.11$ & $0.17 \times 0.15 \times 0.12$ \\
\hline Radiation & $\operatorname{MoK} \alpha(\lambda=0.71073)$ & $\operatorname{MoK} \alpha(\lambda=0.71073)$ \\
\hline $2 \Theta$ range for data collection $/{ }^{\circ}$ & 7.168 to 60.054 & 5.628 to 61.054 \\
\hline Index ranges & $\begin{array}{l}-10 \leq \mathrm{h} \leq 10,-16 \leq \mathrm{k} \leq 16 \\
-15 \leq 1 \leq 15\end{array}$ & $\begin{array}{l}-15 \leq \mathrm{h} \leq 15,-25 \leq \mathrm{k} \leq \\
25,-17 \leq 1 \leq 18\end{array}$ \\
\hline Reflections collected & 8839 & 15050 \\
\hline Independent reflections & $\begin{array}{l}2628\left[R_{\text {int }}=0.0301,\right. \\
\left.R_{\text {sigma }}=0.0374\right]\end{array}$ & $\begin{array}{l}3695\left[R_{\text {int }}=0.0262,\right. \\
\left.R_{\text {sigma }}=0.0242\right]\end{array}$ \\
\hline Data/restraints/parameters & $2628 / 0 / 117$ & $3695 / 0 / 132$ \\
\hline Goodness-of-fit on $\mathrm{F}^{2}$ & 1.025 & 1.051 \\
\hline Final R indexes $[\mathrm{I}>=2 \sigma(\mathrm{I})]$ & $\begin{array}{l}\mathrm{R}_{1}=0.0552 \\
\mathrm{wR}_{2}=0.1507\end{array}$ & $\begin{array}{l}\mathrm{R}_{1}=0.0322 \\
\mathrm{wR}_{2}=0.0792\end{array}$ \\
\hline Final $\mathrm{R}$ indexes [all data] & $\begin{array}{l}\mathrm{R}_{1}=0.0884 \\
\mathrm{wR}_{2}=0.1733\end{array}$ & $\begin{array}{l}\mathrm{R}_{1}=0.0493 \\
\mathrm{wR}_{2}=0.0875\end{array}$ \\
\hline Largest diff. peak/hole / e $\AA^{-3}$ & $0.93 /-0.55$ & $0.80 /-0.49$ \\
\hline
\end{tabular}

\section{Results and discussion}

\subsection{Description of the molecular structures}

The reaction of thiophene-2-carboxylic hydrazide with $\mathrm{Cu}(\mathrm{OAc})_{2} \cdot \mathrm{H}_{2} \mathrm{O}$ with $2: 1$ molar ratio in the presence of sodium hydroxide in a mixture of ethanol-acetone (3:1) affords green crystals of $\left[\mathrm{Cu}(\mathrm{L})_{2}\right]$ (1). The use of $\mathrm{CuCl}_{2} \cdot 2 \mathrm{H}_{2} \mathrm{O}$ affords a different di- $\mu$-chloro bridged $\mathrm{Cu}$ (II) complex $\left[\mathrm{Cu}_{2}(\mu-\mathrm{Cl})_{2}(\mathrm{HL})_{2} \mathrm{Cl}_{2}\right]$ (2). Single crystal X-ray diffraction analyses reveal that the two compounds crystallize in the monoclinic space groups $P 2_{1} / n$ and $C 2 / c$ for $\mathbf{1}$ and 2 
respectively. The crystallographic data of the two complexes are given in Table 1 and selected bond lengths and angles are given in Table 2.

Table 2: Bond Lengths and Bond Angles for 1 and 2.

\begin{tabular}{|c|c|c|c|c|c|c|}
\hline \multicolumn{7}{|c|}{1} \\
\hline Atom & Atom & Length/Å & Atom & Atom & Atom & Angle $/^{\circ}$ \\
\hline $\mathrm{Cu} 1$ & O1 & $1.890(2)$ & $\mathrm{O} 1$ & $\mathrm{Cu} 1$ & $\mathrm{O} 1^{\mathrm{i}}$ & 180.0 \\
\hline $\mathrm{Cu} 1$ & $\mathrm{O} 1^{\mathrm{i}}$ & $1.890(2)$ & $\mathrm{O} 1$ & $\mathrm{Cu} 1$ & N1 & $81.02(11)$ \\
\hline $\mathrm{Cu} 1$ & N1 & $2.051(3)$ & $\mathrm{O} 1$ & $\mathrm{Cu} 1$ & $\mathrm{~N} 1^{\mathrm{i}}$ & $98.98(11)$ \\
\hline $\mathrm{Cu} 1$ & $\mathrm{~N} 1^{\mathrm{i}}$ & $2.051(3)$ & $\mathrm{O} 1^{\mathrm{i}}$ & $\mathrm{Cu} 1$ & $\mathrm{~N} 1^{\mathrm{i}}$ & $81.02(11)$ \\
\hline S1 & $\mathrm{C} 2$ & $1.714(3)$ & $\mathrm{O} 1^{\mathrm{i}}$ & $\mathrm{Cu} 1$ & N1 & $98.98(11)$ \\
\hline S1 & $\mathrm{C} 5$ & $1.684(4)$ & $\mathrm{N} 1^{\mathrm{i}}$ & $\mathrm{Cu} 1$ & N1 & $180.00(14)$ \\
\hline N1 & $\mathrm{N} 2$ & $1.416(3)$ & & & & \\
\hline N1 & C6 & $1.299(5)$ & & & & \\
\hline $\mathrm{N} 2$ & $\mathrm{C} 1$ & $1.292(4)$ & & & & \\
\hline \multicolumn{7}{|c|}{ Symmetry code: (i) -X,1-Y,1-Z } \\
\hline \multicolumn{7}{|c|}{2} \\
\hline Atom & Atom & Length/̊̊ & Atom & Atom & Atom & Angle $/^{\circ}$ \\
\hline $\mathrm{Cu} 1$ & $\mathrm{Cl1}$ & $2.3612(6)$ & $\mathrm{Cl}^{\mathrm{i}}$ & $\mathrm{Cu} 1$ & $\mathrm{Cl1}$ & $85.12(2)$ \\
\hline $\mathrm{Cu} 1$ & $\mathrm{Cl}^{\mathrm{i}}$ & $2.2587(6)$ & $\mathrm{Cl}^{\mathrm{i}}$ & $\mathrm{Cu} 1$ & $\mathrm{Cl} 2$ & $94.09(2)$ \\
\hline $\mathrm{Cu} 1$ & $\mathrm{Cl} 2$ & $2.2780(6)$ & $\mathrm{Cl} 2$ & $\mathrm{Cu} 1$ & $\mathrm{Cl} 1$ & $154.37(3)$ \\
\hline $\mathrm{Cu} 1$ & $\mathrm{O} 1$ & $2.1927(15)$ & $\mathrm{O} 1$ & $\mathrm{Cu} 1$ & $\mathrm{Cl}^{\mathrm{i}}$ & $102.64(4)$ \\
\hline $\mathrm{Cu} 1$ & $\mathrm{~N} 1$ & $2.0075(18)$ & $\mathrm{O} 1$ & $\mathrm{Cu} 1$ & $\mathrm{Cl1}$ & $103.12(5)$ \\
\hline S1 & $\mathrm{C} 2$ & $1.715(2)$ & $\mathrm{O} 1$ & $\mathrm{Cu} 1$ & $\mathrm{Cl} 2$ & $102.04(5)$ \\
\hline S1 & $\mathrm{C} 5$ & $1.695(3)$ & N1 & $\mathrm{Cu} 1$ & $\mathrm{C} 11$ & $88.49(5)$ \\
\hline N1 & $\mathrm{N} 2$ & $1.390(2)$ & N1 & $\mathrm{Cu} 1$ & $\mathrm{Cl}^{\mathrm{i}}$ & $173.40(5)$ \\
\hline N1 & C6 & $1.284(3)$ & N1 & $\mathrm{Cu} 1$ & $\mathrm{Cl} 2$ & $92.37(5)$ \\
\hline \multirow[t]{2}{*}{$\mathrm{N} 2$} & $\mathrm{C} 1$ & $1.359(3)$ & N1 & $\mathrm{Cu} 1$ & $\mathrm{O} 1$ & $77.22(6)$ \\
\hline & & & $\mathrm{Cu} 1^{\mathrm{i}}$ & $\mathrm{Cl} 1$ & $\mathrm{Cu} 1$ & $93.39(2)$ \\
\hline \multicolumn{7}{|c|}{ Symmetry code: (i) $-\mathrm{X},+\mathrm{Y},{ }_{1} /{ }_{2}-\mathrm{Z}$} \\
\hline
\end{tabular}

As shown in Figure 1, compound $\mathbf{1}$ is square-planar copper (II) complex with two chelating $\mathrm{L}^{-1}$ ligand. The asymmetric unit consist in a half molecule with $50 \%$ occupancy of metal ion and one $\mathrm{L}^{-1}$ ligand, the coordination sphere is formed by two carbonyl oxygen atoms $\mathrm{O} 1, \mathrm{O} 1-\mathrm{i}$ and two imine nitrogen atoms N1, N1-i, from two chelating bidentate ligands species. The $\mathrm{Cu}-\mathrm{O}$ and $\mathrm{Cu}-\mathrm{N}$ distances of bidentate ligand are respectively $1.890(2)$ and 2.051(3). The values of $\mathrm{O} 1-\mathrm{Cu}-\mathrm{N} 1$ and $\mathrm{O} 1-\mathrm{Cu}-\mathrm{N} 1-\mathrm{i}$ angles are respectively $81.02(11)^{\circ}$ and $98.98(11)^{\circ}$. 


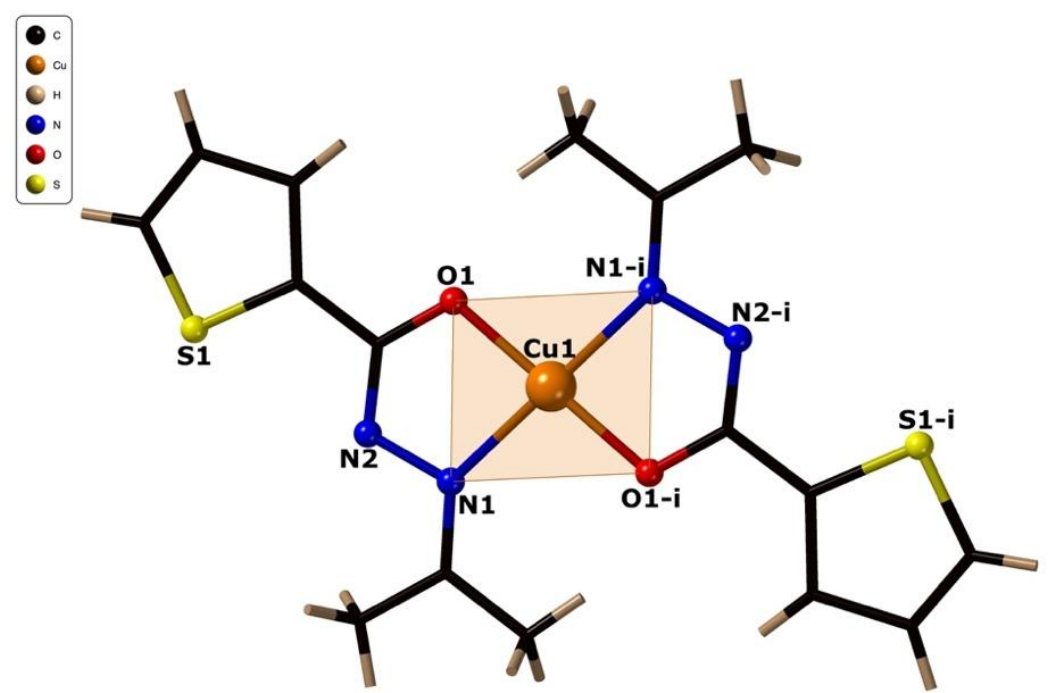

Figure 1. Molecular structure of $\left[\mathrm{Cu}(\mathrm{L})_{2}\right](1)$.

Symmetry operators for generating equivalent positions: (i) : $-\mathrm{x},-\mathrm{y}+1,-\mathrm{z}+1$.

The structure of $\mathbf{2}$ consists of a centrosymmetric dinuclear complex in which each $\mathrm{Cu}$ (II) ion is coordinated to one chelating HL ligand, through carbonyl oxygen $\mathrm{O} 1$ and imine nitrogen $\mathrm{N} 1$ with elongated $\mathrm{Cu} 1-\mathrm{O} 1=2.1927(15) \AA$ and $\mathrm{Cu} 1-\mathrm{N} 1=2.0075(18) \AA$. Both $\mathrm{Cu}$ (II) ions are linked to each other by asymmetric double chloro bridge $(\mu-\mathrm{Cl})[\mathrm{Cu} 1-\mathrm{Cl} 1=2.3612(6) \AA$ and $\mathrm{Cu} 1-\mathrm{Cl} 1-\mathrm{i}=2.2587(6) \AA]$, forming a $\mathrm{Cu}_{2} \mathrm{Cl}_{2}$ rectangular core with an intermetallic $\mathrm{Cu} . . . \mathrm{Cu}$ distance of 3.363(2). The fifth coordination site around each copper is occupied by a terminal chloride $\mathrm{Cl} 2$ with $\mathrm{Cu} 1-\mathrm{Cl} 2=2.278(6) \AA$. (Figure 2) Each $\mathrm{Cu}$ (II) ion is in highly distorted square-pyramidal coordination environment with trigonality index parameter $\tau=$ 0.317. The parameter $\tau$ is determined by the relation $\tau=(\beta-\alpha) / 60$ (where $\alpha$ and $\beta$ are the larger basal angles with $\beta>\alpha$ ) and its value may vary from 0 , representing ideal squarpyramidal geometry to 1 , denoting ideal trigonal bipyramid geometry. ${ }^{[46]}$ This distortion has been observed for similar compounds. ${ }^{[30,47]}$ In addition, the SHAPE analysis ${ }^{[48]}$ that has been carried out to ascertain the coordination geometry adopted by the $\mathrm{Cu}$ (II) centers reveals that it can be best described as distorted vacant ocatahedron (minimum CShM value of 2.283, Table 3) when compared to the square pyramidal geometry (minimum CShM value of 2.524, Table 3). The large values point out however a distorted geometry. 
Table 3: SHAPE analysis for 2

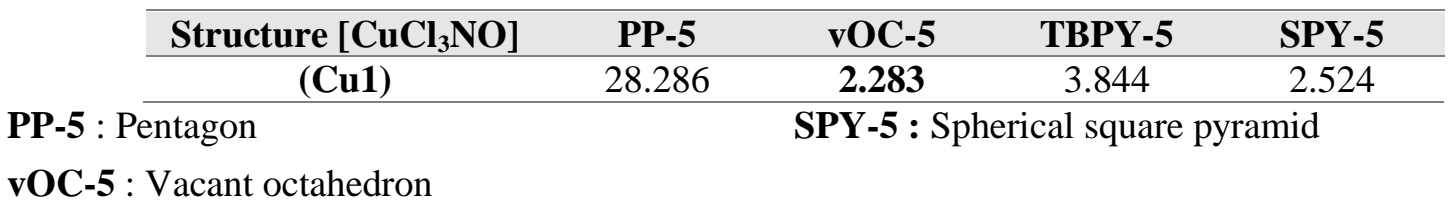

TBPY-5 : Trigonal bipyramid

Around each $\mathrm{Cu}(\mathrm{II})$ center, imine N1(/1-i), bridging chloride $\mathrm{Cl1}(/ 1-\mathrm{i}), \mathrm{Cl1}-\mathrm{i}(/ 1)$ and terminal chloride $\mathrm{Cl} 2$ (2-i) form the basal plane in the square pyramid. Each cooper ion is $0.256 \AA$ lifted towards the apical position occupied by $\mathrm{O} 1(1-\mathrm{i})$. The $\mathrm{Cu}-\mathrm{Cl}-\mathrm{Cu}$ bridging angle is equal to $93.39(2)^{\circ}$.
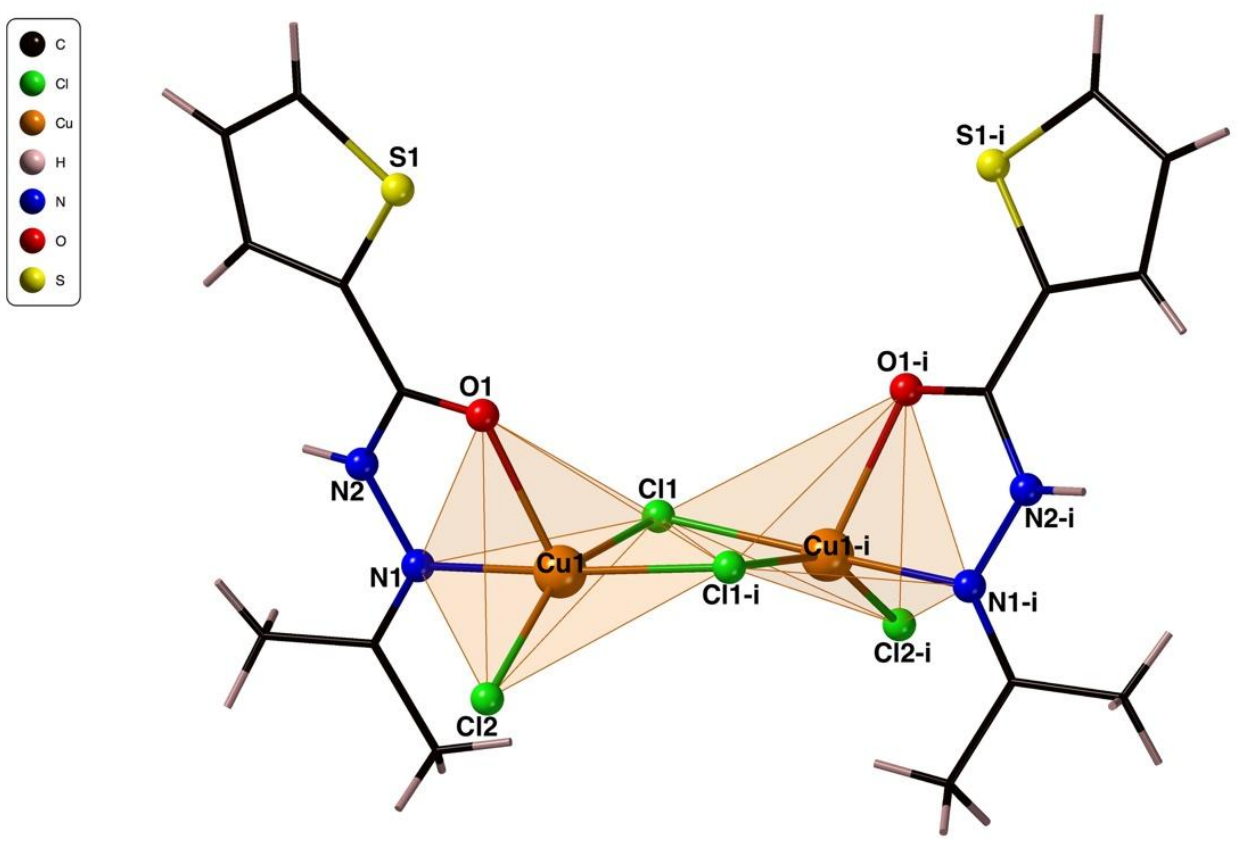

Figure 2. Molecular structure of $\left[\mathrm{Cu}_{2}(\mu-\mathrm{Cl})_{2}(\mathrm{HL})_{2} \mathrm{Cl}_{2}\right](2)$.

Symmetry operators for generating equivalent positions: (i) : $x,-y+2, z+1 / 2$.

The three-dimensional network of the structures is assured by weak hydrogen bond CH...O and Van der Waals interactions for compound 1 (Figure 3, Table 4-1), and weak hydrogen bonds N-H...Cl and C-H...N for 2 (Figure 4, Table 4-2). 


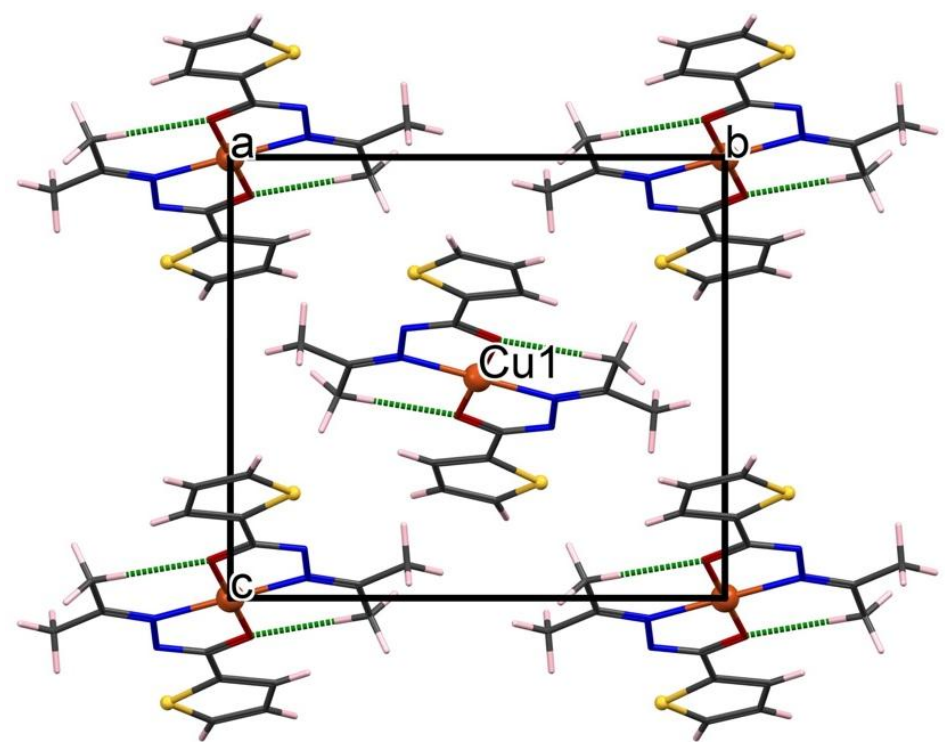

Figure 3: Projection of the crystal structure along the $a$ crystallographic axis showing the packing for $\mathbf{1}$. The hydrogen bonding is indicated by green dashed lines.

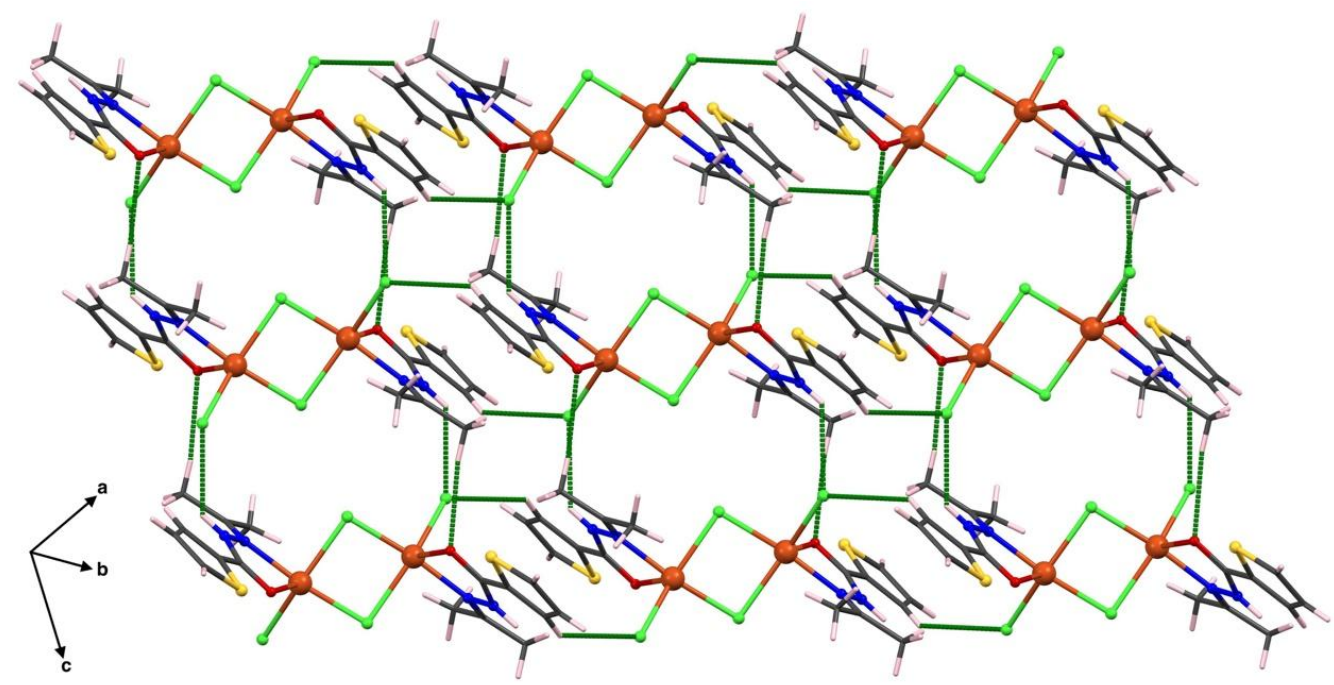

Figure 4: Perspective view of the crystal structure of $\mathbf{2}$ showing the two-dimensional network connected through the hydrogen bonds in dashed green lines

Table 4: Hydrogen-bond geometry $\left(\AA{ }^{\circ}\right)$ for 1-2

\begin{tabular}{|c|c|c|c|c|}
\hline \multicolumn{5}{|c|}{1} \\
\hline$D-\mathrm{H} \cdots A$ & $D-\mathrm{H}$ & $\mathrm{H} \cdots A$ & $D \cdots A$ & $D-\mathrm{H} \cdots A$ \\
\hline $\mathrm{C} 8-\mathrm{H} 8 \mathrm{C} \cdots \mathrm{O} 1^{\mathrm{i}}$ & 0.960 & 2.100 & $2.981(4)$ & 152.00 \\
\hline \multicolumn{5}{|c|}{ Symmetry code: (i) $-x,-y+1,-z+1$} \\
\hline \multicolumn{5}{|c|}{0} \\
\hline$D-\mathrm{H} \cdots A$ & $D-\mathrm{H}$ & $\mathrm{H} \cdots A$ & $D \cdots A$ & $D-\mathrm{H} \cdots A$ \\
\hline $\mathrm{N} 2-\mathrm{H} 2 \cdots \mathrm{Cl} 2^{1}$ & 0.860 & 2.700 & $3.350(2)$ & 133.00 \\
\hline $\mathrm{C} 7-\mathrm{H} 7 \mathrm{C} \cdots \mathrm{N} 2$ & 0.960 & 2.460 & $2.798(3)$ & 101.00 \\
\hline
\end{tabular}




\subsection{Magnetic properties}

Magnetic measurement of 2 (shown in Figure 5) was carried out on a powdered sample with a magnetic field of $1000 \mathrm{Oe}$ in the temperature range of $1.8-300 \mathrm{~K}$. The room temperature $\chi T$ value of $0.82 \mathrm{~cm}^{3} \cdot \mathrm{K} \cdot \mathrm{mol}^{-1}$ is in perfect agreement with the expected value for two uncoupled copper (II) ions $(S=1 / 2, g=2.1)$. Upon cooling a decrease of $\chi T$ could be observed and suggest the occurrence of antiferromagnetic interactions between the spin carriers to reach the value of $0.07 \mathrm{~cm}^{3} \cdot \mathrm{K} \cdot \mathrm{mol}^{-1}$ at $1.8 \mathrm{~K}$.

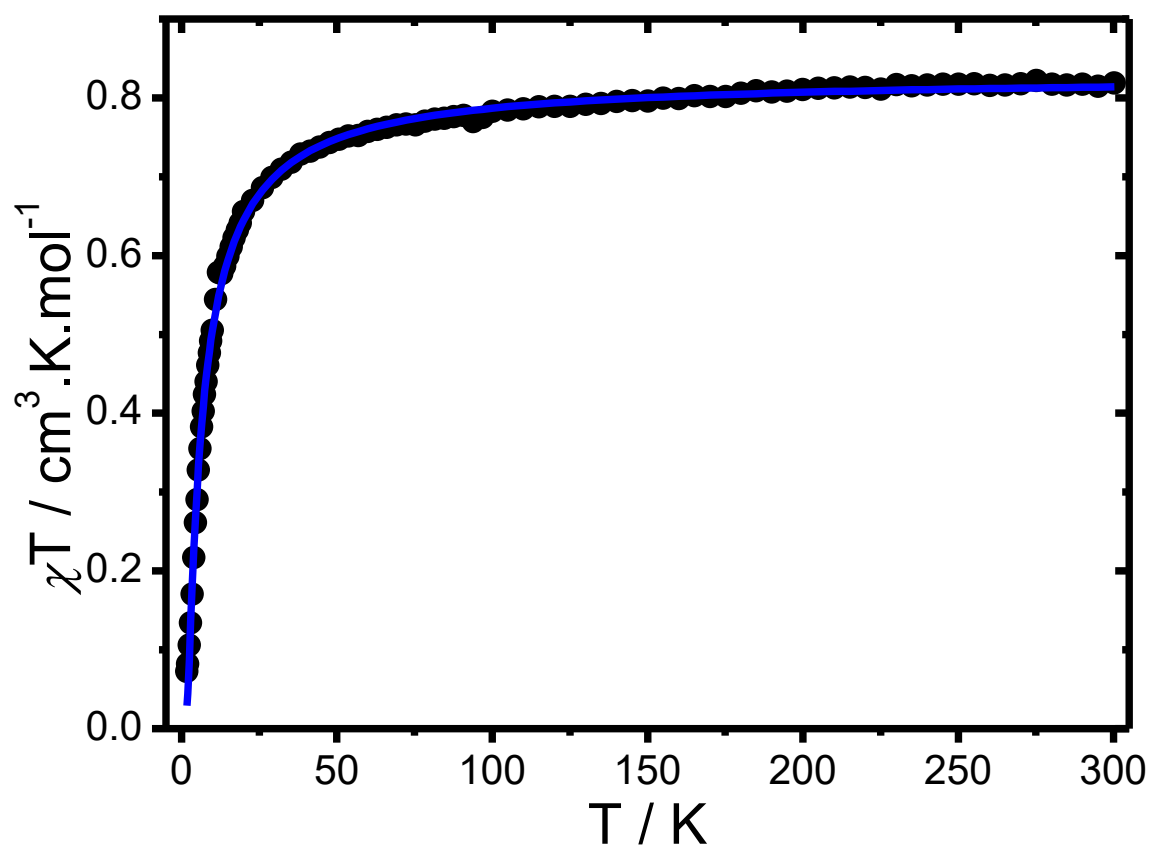

Figure 5. Temperature dependence of $\chi T$ under an applied magnetic field of 1000 Oe for $\mathbf{2}$. The blue solid line corresponds to the fit of the data.

The experimental magnetic data could be fitted using the PHI software. ${ }^{[49]}$ based derived equation of Bleaney-Bower expression for two interacting $\mathrm{Cu}$ (II) ions $(S=1 / 2)$ with the Hamiltonian in the form $\mathrm{H}=-2 \mathrm{JS} 1 \cdot \mathrm{S} 2{ }^{[23,50]}$ with an additional intermolecular interaction $z J$ term.

The best fit parameters were found for $J=-2.99 \pm 0.03 \mathrm{~cm}^{-1}, g=2.106 \pm 0.002, z J=-0.94 \pm$ 0.03. In chloro-bridged dinuclear complexes, the sign and magnitude of the exchange interaction is known to depend on numerous parameters such as the coordination geometry of the copper ion, the nature of the terminal ligands, the $\mathrm{Cu}-\mathrm{Cl}-\mathrm{Cu}$ bridging angle and intramolecular $\mathrm{Cu}-\mathrm{Cu}$ distance. ${ }^{[27]}$ In the absence of others related complexes with similar ligands, it is difficult to identify what are the key parameters that affect the exchange interaction. 
Magneto-structural correlations in dinuclear copper (II) complexes have been largely studied in order to explain and predict the magnetic properties of these compounds. It has been shown that exchange interaction is affected by several structural parameters such as the identity of the bridging atoms $(\mathrm{X})$, the $\mathrm{Cu}-\mathrm{Cu}^{\prime}$ distances, the bridging angles $\mathrm{Cu}-\mathrm{X}-\mathrm{Cu}^{\prime}(\alpha)$ and the coordination geometries around the copper ions. ${ }^{[31,34,51-54]}$ For instance, coupling constant ranging from -132 to $45.1 \mathrm{~cm}^{-1}$ have been reported. ${ }^{[27]}$ In generally, the magnetic coupling between the two pentacoordinated $\mathrm{Cu}$ ions through chloro bridges is expected to be weaker than that observed in analogous systems with oxo or hydroxo ligands. This could be ascribed to the $\mathrm{Cu}-\mathrm{Cl}$ distances that are larger, reducing the efficiency of the coupling. ${ }^{[30,55,56]}$ For doubly chloro-bridged $\mathrm{Cu}(\mathrm{II})$ complexes, some works have related the exchange coupling with the bridging angle $(\mathrm{Cu}-\mathrm{Cl}-\mathrm{Cu}) \quad(\varphi)$ and the $\mathrm{Cu}-\mathrm{Cl}_{\text {bridge }}$ distance $(\mathrm{R})$ particularly expressed by $\varphi / \mathrm{R}$ ratio. ${ }^{[57-59]}$ In a similar manner that for oxo or hydroxo systems, a switch in the sign of the magnetic interactions could be observed depending on the bridging angle. In the present case, the relatively small antiferromagnetic coupling constant of about $-3 \mathrm{~cm}^{-1}$ suggests that the bridging angle of $93.39^{\circ}$ is close to this threshold. In other works, ${ }^{[34,} \mathbf{3 6}, \mathbf{6 0}, \mathbf{6 1 ]}$ the sign and magnitude of coupling constant $J$ are also related with geometry around the paramagnetic centers. Moreover, in pentacoordinated $\mathrm{Cu}(\mu-$ $\mathrm{Cl})_{2} \mathrm{Cu}$ dinuclear complexes, the distortion of the coordination geometry consititutes also an important factor that may affect the the magnetic coupling.

\subsection{Antioxidant activity}

Previous research has revealed that sulfur-containing amino acids have valuable antioxidant activities based on in vitro assays, including DPPH, ABTS, superoxide radical scavenging activities, ferric reducing antioxidant power, hydrogen peroxide scavenging, and metal chelating activities. ${ }^{[62]}$ Both of our Schiff base complexes have demonstrated a moderate antioxidant effect; compound $\mathbf{1}$ was more efficient than compound 2, whether for the inhibition of free radical ABTS, or the reduction of copper (II)-neocuproine [Cu(II)-Nc] formed during the reaction of CUPRAC. Table 4 shows that 1 has lower IC50 and A0.5 values compared with $\mathbf{2}$ but are modestly higher than those of the reference compounds (BHA, BHT) which indicates both compounds have moderate antioxidant activity. It has been proved that Schiff base ligands and their copper complexes showed a significant free radical scavenging action. This may be due to the presence of -NH groups which may donate an electron or hydrogen atom and form a stable free radical. ${ }^{[63]}$ On the grounds of our products structure and supporting on others studies results and analysis, we strongly suggest that there 
was a powerful synergic antioxidant effect of the sulfur coupled and incorporated atom within the current products molecular structure.

Table 4: Antioxidant activity for 1 and 2

A. ABTS radical scavenging potential of $\mathbf{1}$ and $\mathbf{2}$

\begin{tabular}{|l|l|l|l|l|}
\hline \multicolumn{5}{|c|}{ \% Inhibition in ABTS assay } \\
\hline Products & $\mathbf{1}$ & $\mathbf{2}$ & BHA $^{\mathrm{b}}$ & BHT $^{\mathrm{b}}$ \\
\hline IC $50 \mu \mathrm{M}$ & $73.57 \pm 2.52$ & $109.73 \pm 2.41$ & $20.02 \pm 0.77$ & $6.79 \pm 1.0$ \\
\hline
\end{tabular}

B. Cupric ion reducing antioxidant capacity for $\mathbf{1}$ and $\mathbf{2}$

\begin{tabular}{|l|l|l|l|l|}
\hline \multicolumn{5}{|c|}{ Absorbances in CUPRAC assay } \\
\hline Products & $\mathbf{1}$ & $\mathbf{2}$ & BHA $^{\mathrm{b}}$ & BHT $^{\mathrm{b}}$ \\
\hline A $0.5 \mu \mathrm{M}$ & $254.44 \pm 1.73$ & $256.24 \pm 0.93$ & $16.82 \pm 2.34$ & $7.67 \pm 1.37$ \\
\hline
\end{tabular}

\subsection{Anti acetylcholinesterase activity}

A potent AChE inhibition was asserted by $\mathbf{1}$ and $\mathbf{2}$, as indicated by their IC50 values (the quantity that was sufficient to hinder $50 \%$ of the AChE enzyme in the reaction), which are as low as Galantamine (Table 5). While the in vitro neuroprotective potential of $\mathbf{2}$ was greater than for $\mathbf{1}$, it is important to note that $\mathbf{2}$ was more effective than the reference compound Galentamine. A previous study reported that all of the Schiff bases showed high AChE inhibition, however none of them was more potent than Galanthamine. ${ }^{[64]}$ Regarding structures of $\mathbf{1}$ and 2, the main difference between them is that there are two copper atoms in each molecule of $\mathbf{2}$ while there is only a single copper atom in $\mathbf{1}$, so we believe that the response against $\mathrm{AChE}$ is proportional to the amount of copper; the activity of $\mathbf{2}$ is twice as effective as 1. Other researchers have shown that the presence of heavy metals, such as chromium, copper, and mercury, strongly inhibited the activity of P. javanicus AChE to below $50 \%$, while several pairwise combinations of different metals exhibited synergistic inhibiting effects on the enzyme, greater than was found for the individual metals; this was especially true for chromium, copper, and mercury. ${ }^{[65]}$ On the other hand, we suspect that the presence of the sulfur atom in our two compounds has not only shown antioxidant activities, but also plays a considerable effect on AChE inhibition, as a previous study reported the binding of the sulfur atom to the anionic site of cholinesterase was the major factor in cholinesterase inhibition by thioether carbamates. ${ }^{[6]}$

\section{Table 5: Anti-acetylcholinesterase activity for $\mathbf{1}$ and $\mathbf{2}$}




\begin{tabular}{|l|l|l|l|}
\hline \multicolumn{4}{|c|}{ Acetylcholinesterase inhibitory activity } \\
\hline Products & $\mathbf{1}$ & $\mathbf{2}$ & Galantamine $^{\mathrm{b}}$ \\
\hline IC $50 \mu \mathrm{M}$ & $22.46 \pm 0.37$ & $10.23 \pm 0.37$ & $11.33 \pm 1.01$ \\
\hline
\end{tabular}

${ }^{\text {a }}$ Values expressed are means \pm S.D. of three parallel measurements.

${ }^{\mathrm{b}}$ Reference compounds.

\section{Conclusion}

In conclusion, two new complexes of $\mathrm{Cu}$ (II) based on $\mathrm{N}^{\prime}$-(propan-2-ylidene) thiophene-2-carbohydrazide ligand were synthetized and structurally characterized, by using single crystal X-ray crystallographic tools. The two complexes exhibit different mono and dinuclear structures with square planar geometry around the $\mathrm{Cu}(\mathrm{II})$ for $\mathbf{1}$ and square pyramidal geometry for 2 . The magnetic properties of di- $\mu$-chloro bridged $\mathrm{Cu}$ (II) complex indicate antiferromagnetic intra dimer coupling with $J=-2.99 \mathrm{~cm}^{-1}$. This value agrees with the magnetic behaviour expected by such type of compounds with close values of $\mathrm{Cu}-\mathrm{Cu}$ and $\mathrm{Cu}$ $\mathrm{Cl}$ distances and $\mathrm{Cu}-\mathrm{Cl}-\mathrm{Cu}$ angle. Due to the presence of - $\mathrm{NH}$ groups and sulfur in the structure of $\mathbf{1}$ and $\mathbf{2}$, these compounds have a noticeable effect on the inhibition of free radical ABTS or the reduction of copper(II)-neocuproine [Cu(II)-Nc] CUPRAC, compound 1 was more active than $\mathbf{2}$ for the two methods. However, for AChE inhibition, compound $\mathbf{2}$ with di$\mu$-chloro bridged $\mathrm{Cu}(\mathrm{II})$ was more effective than the reference compound Galentamine; this phenomenal finding requires supplement studies concerning in vivo evaluation, to strengthen the current result as to list this product among the panel of the most powerful antialzheimer standards.

\section{Acknowledgements}

The authors are grateful to University Frères Mentouri de Constantine, MESRS (Algeria). The Algerian PRFU project (2018-2021: grant $\mathrm{N}^{\circ}$ B00L01UN250120180004) is also acknowledged. J. L thank the University of Montpellier, CNRS for financial support and PAC of ICGM. 


\section{References}

[1] N. BHAVE, P. BAHAD, P. SONPAROTE, A. ASWAR, Journal of the Indian Chemical Society, 79 (2002) 342-344.

[2] P. Souza, J.A. Garcia-Vázquez, J.R. Masaguer, Transition Metal Chemistry, 10 (1985) 410-412.

[3] R. Bikas, H. Hosseini-Monfared, M. Siczek, S. Demeshko, B. Soltani, T. Lis, Inorganic Chemistry Communications, 62 (2015) 60-63.

[4] D. Laziz, C. Beghidja, N. Baali, B. Zouchoune, A. Beghidja, Inorganica Chimica Acta, 497 (2019) 119085 .

[5] H. Wang, H. Yuan, S. Li, Z. Li, M. Jiang, Bioorganic \& Medicinal Chemistry Letters, 26 (2016) 809-813.

[6] E. Yousif, A. Majeed, K. Al-Sammarrae, N. Salih, J. Salimon, B. Abdullah, Arabian Journal of Chemistry, 10 (2017) S1639-S1644.

[7] The Chemistry of Nickel-Containing Enzymes, in: Progress in Inorganic Chemistry, pp. 493-597.

[8] N. Zhang, Y.-h. Fan, Z. Zhang, J. Zuo, P.-f. Zhang, Q. Wang, S.-b. Liu, C.-f. Bi, Inorganic Chemistry Communications, 22 (2012) 68-72.

[9] G.-L. Li, W.-Q. Cheng, L.-F. Zhang, Z.-H. Ni, M.-M. Yu, H.-Z. Kou, Transition Metal Chemistry, 37 (2012) 469-474.

[10] W.-Y. Huang, Z.-L. Chen, K. Wang, X. Zhou, F.-P. Liang, Transition Metal Chemistry, 37 (2012) 291-296.

[11] K.C. Gupta, A.K. Sutar, Coordination Chemistry Reviews, 252 (2008) 1420-1450.

[12] Y. Huang, T. Liu, J. Lin, J. Lü, Z. Lin, R. Cao, Inorganic Chemistry, 50 (2011) 2191-2198.

[13] S. Bhunia, S. Koner, Polyhedron, 30 (2011) 1857-1864.

[14] O. Pouralimardan, A.-C. Chamayou, C. Janiak, H. Hosseini-Monfared, Inorganica Chimica Acta, 360 (2007) 1599-1608.

[15] R. Manikandan, P. Viswanathamurthi, M. Muthukumar, Spectrochimica Acta Part A: Molecular and Biomolecular Spectroscopy, 83 (2011) 297-303.

[16] M. Ibrahim, A. Khan, M. Ikram, S. Rehman, M. Shah, H.A. Un Nabi, A. Ahuchaogu, AJOCS, 2 (2017) 1-12.

[17] M. Kumar, T. Padmini, K. Ponnuvel, Journal of Saudi Chemical Society, 21 (2017) S322-S328.

[18] F.H. Allen, O. Kennard, D.G. Watson, L. Brammer, A.G. Orpen, R. Taylor, Journal of the Chemical Society, Perkin Transactions 2, (1987) S1-S19.

[19] K.-K. Bedia, O. Elçin, U. Seda, K. Fatma, S. Nathaly, R. Sevim, A. Dimoglo, European Journal of Medicinal Chemistry, 41 (2006) 1253-1261.

[20] H. Yin, S. Chen, L. Li, D. Wang, Inorganica Chimica Acta, 360 (2007) 2215-2223.

[21] E. Mukwevho, Z. Ferreira, A. Ayeleso, Molecules, 19 (2014).

[22] E.E. Battin, J.L. Brumaghim, Cell Biochemistry and Biophysics, 55 (2009) 1-23.

[23] Y. Sikdar, R. Modak, D. Bose, S. Banerjee, D. Bieńko, W. Zierkiewicz, A. Bieńko, K. Das Saha, S. Goswami, Dalton Transactions, 44 (2015) 8876-8888.

[24] J.A. Carrabine, M. Sundaralingam, Journal of the American Chemical Society, 92 (1970) 369371.

[25] R.F. Drake, V.H. Crawford, N.W. Laney, W.E. Hatfield, Inorganic Chemistry, 13 (1974) 12461249.

[26] S. Ouilia, C. Beghidja, A. Beghidja, L. Belkhiri, P. Rabu, Inorganica Chimica Acta, 476 (2018) 54-60.

[27] A. Rodríguez-Fortea, P. Alemany, S. Alvarez, E. Ruiz, Inorganic Chemistry, 41 (2002) 37693778.

[28] Y.-M. Lee, H.-W. Lee, Y.-I. Kim, Polyhedron, 24 (2005) 377-382. 
[29] W.A. Alves, R.H.d.A. Santos, A. Paduan-Filho, C.C. Becerra, A.C. Borin, A.M.D.C. Ferreira, Inorganica Chimica Acta, 357 (2004) 2269-2278.

[30] M. Rodríguez, A. Llobet, M. Corbella, A.E. Martell, J. Reibenspies, Inorganic Chemistry, 38 (1999) 2328-2334.

[31] V.H. Crawford, H.W. Richardson, J.R. Wasson, D.J. Hodgson, W.E. Hatfield, Inorganic Chemistry, 15 (1976) 2107-2110.

[32] S. Demeshko, G. Leibeling, S. Dechert, F. Meyer, Dalton Transactions, (2004) 3782-3787.

[33] E. Gungor, H. Kara, Inorganica Chimica Acta, 384 (2012) 137-142.

[34] M. Rodríguez, A. Llobet, M. Corbella, Polyhedron, 19 (2000) 2483-2491.

[35] A. Sasmal, S. Shit, C. Rizzoli, H. Wang, C. Desplanches, S. Mitra, Inorganic Chemistry, 51 (2012) 10148-10157.

[36] K. Skorda, T.C. Stamatatos, A.P. Vafiadis, A.T. Lithoxoidou, A. Terzis, S.P. Perlepes, J. Mrozinski, C.P. Raptopoulou, J.C. Plakatouras, E.G. Bakalbassis, Inorganica Chimica Acta, 358 (2005) 565-582.

[37] B. Murphy, B. Hathaway, Coordination Chemistry Reviews, 243 (2003) 237-262.

[38] R. Re, N. Pellegrini, A. Proteggente, A. Pannala, M. Yang, C. Rice-Evans, Free radical biology and medicine, 26 (1999) 1231-1237.

[39] R. Apak, K. Güçlü, M. Özyürek, S.E. Karademir, Journal of agricultural and food chemistry, 52 (2004) 7970-7981.

[40] G.L. Ellman, K.D. Courtney, V. Andres Jr, R.M. Featherstone, Biochemical pharmacology, 7 (1961) 88-95.

[41] Bruker APEX2 and SAINT, Bruker AXS Inc., Madison, Wisconsin, USA., (2007).

[42] G.M. Sheldrick, Acta Cryst., C71 (2015) 3.

[43] D.C. Palmer, CrystalMaker. CrystalMaker Software Ltd, Begbroke, Oxfordshire, England., (2014).

[44] C.F. Macrae, P.R. Edgington, P. McCabe, E. Pidcock, G.P. Shields, R. Taylor, M. Towler, J. van de Streek, J. Appl. Cryst., 39 (2006) 453-457.

[45] A. L. Spek, Acta Cryst., D65 (2009) 148-155.

[46] A.W. Addison, T.N. Rao, J. Reedijk, J. van Rijn, G.C. Verschoor, Journal of the Chemical Society, Dalton Transactions, (1984) 1349-1356.

[47] P. Kapoor, A.P.S. Pannu, M. Sharma, M.S. Hundal, R. Kapoor, M. Corbella, N. Aliaga-Alcalde, Journal of Molecular Structure, 981 (2010) 40-45.

[48] S. Alvarez, P. Alemany, D. Casanova, J. Cirera, M. Llunell, D. Avnir, Coordination Chemistry Reviews, 249 (2005) 1693-1708.

[49] N.F. Chilton, R.P. Anderson, L.D. Turner, A. Soncini, K.S. Murray, J. Comput. Chem., 34 (2013) $1164-1175$.

[50] O. Kahn, Molecular Magnetism, VCH, New York, 1993.

[51] T. Rojo, M.I. Arriortua, J. Ruiz, J. Darriet, G. Villeneuve, D. Beltran-Porter, Journal of the Chemical Society, Dalton Transactions, (1987) 285-291.

[52] P.J. Hay, J.C. Thibeault, R. Hoffmann, Journal of the American Chemical Society, 97 (1975) 4884-4899.

[53] K. Das, A. Datta, C. Sinha, J.-H. Huang, E. Garribba, C.-S. Hsiao, C.-L. Hsu, ChemistryOpen, 1 (2012) 80-89.

[54] T. Rojo, M.I. Arriortua, J.L. Mesa, R. Cortes, G. Villeneuve, D. Beltran, Inorganica Chimica Acta, 134 (1987) 59-66.

[55] S.-C. Cheng, H.-H. Wei, Inorganica Chimica Acta, 340 (2002) 105-113.

[56] X.-H. Bu, M. Du, L. Zhang, Z.-L. Shang, R.-H. Zhang, M. Shionoya, Journal of the Chemical Society, Dalton Transactions, (2001) 729-735. 
[57] S.G.N. Roundhill, D.M. Roundhill, D.R. Bloomquist, C. Landee, R.D. Willett, D.M. Dooley, H.B. Gray, Inorganic Chemistry, 18 (1979) 831-835.

[58] W.E. Marsh, W.E. Hatfield, D.J. Hodgson, Inorganic Chemistry, 21 (1982) 2679-2684.

[59] W.E. Marsh, K.C. Patel, W.E. Hatfield, D.J. Hodgson, Inorganic Chemistry, 22 (1983) 511-515.

[60] H. Grove, J. Sletten, M. Julve, F. Lloret, Journal of the Chemical Society, Dalton Transactions, (2001) 2487-2493.

[61] S. Thakurta, P. Roy, G. Rosair, C.J. Gómez-García, E. Garribba, S. Mitra, Polyhedron, 28 (2009) 695-702.

[62] J.-H. Kim, H.-J. Jang, W.-Y. Cho, S.-J. Yeon, C.-H. Lee, Arabian Journal of Chemistry, (2018).

[63] K. Hariprasath, I. Sudheer babu, Asian Journal of Pharmaceutical Analysis and Medicinal Chemistry, 2 (2014) 119-126.

[64] B. M. Abd Razik, H. Osman, M. O. Ezzat, A. Basiri, A. Salhin, Y. Kia, V. Murugaiyah, Medicinal Chemistry, 12 (2016) 527-536.

[65] M.K. Sabullah, M.R. Sulaiman, M.Y.A. Shukor, M.A. Syed, N.A. Shamaan, A. Khalid, S.A. Ahmad, The Scientific World Journal, 2014 (2014).

[66] A.M. Mahfouz, R.L. Metcalf, T.R. Fukuto, Journal of agricultural and food chemistry, 17 (1969) 917-922. 